\title{
MAN WITH A MOVIE CAMERA: ECONOMY OF MOVEMENT AND ASMR VIDEOS ON YOUTUBE
}

\author{
Alina S. Holmowaia ${ }^{a}$, Maria S. Danzis ${ }^{b}$ \\ ${ }^{a}$ Saint Petersburg State University. 5 Mendeleevskaya lin., Saint Petersburg, \\ Russia, 199034. Email: holmowaia[at]gmail.com \\ ${ }^{\mathrm{b}}$ Saint Petersburg State University. 5 Mendeleevskaya lin., Saint Petersburg, \\ Russia, 199034. Email: danzis[at]bk.ru
}

\begin{abstract}
The article examines the ASMR phenomena through the perspective of early USSR philosophy of technic, especially, of the constructivist movement (Gan, Ginzburg) and of works of film director Dziga Vertov. Autonomous sensory meridian response (ASMR) is a tingling sensation that typically begins on the scalp and moves down the back of the neck and upper spine. The aim of research is to reconstruct the notion of «movement», «machine» and «technique» in constructivist writings and to transfer this notion on contemporary media culture. For the analysis authors use ASMR videos on Youtube in order to discover new possible connotations of the term «movement» in a constructivist perspective. The ASMR phenomena could be considered as a merge of Haraway's cyborg metaphor and the constructivist conception of domestic life, movement and technique.
\end{abstract}

\section{Keywords}

youtube; media philosophy; soviet philosophy of technique; constructivism; ASMR; Dziga Vertov

This work is licensed under a Creative Commons Attribution 4.0 International License. 


\title{
ЧЕЛОВЕК С КИНОАППАРАТОМ: ЭКОНОМИКА ДВИЖЕНИЯ И АСМР-ВИДЕО НА ҮОUТUВЕ
}

\author{
Холмовая Алина Сергеевна ${ }^{a}$, Данцис Мария Самуиловна \\ а ФГБОУ ВО «Санкт-Петербургский государственный университет». 199034 Россия, \\ Санкт-Петербург, Менделеевская линия, д. 5. Email: holmowaia[at]gmail.com \\ ${ }^{\mathrm{b}}$ ФГБОУ ВО «Санкт-Петербургский государственный университет». 199034 Россия, \\ Санкт-Петербург, Менделеевская линия, д. 5. Email: danzis[at]bk.ru
}

\section{Аннотация}

Статья посвящена исследованию понятий «движение», «машина», «общественная техника» в работах конструктивистов Алексея Гана и Моисея Гинзбурга, а также в «Варианте манифеста МЫ» Дзиги Вертова. Цель исследования - реконструировать данные понятия в работах конструктивистов и перенести их в сферу современной медиа теории. В своем анализе авторы концентрируются на феномене АСМР-видео, чтобы обнаружить новые возможные коннотации термина «движение» в перспективе советских конструктивистов. Автономная сенсорная меридиональная реакция (ASMR) - это покалывание, которое обычно начинается на коже головы и опускается вниз по задней части шеи.Явление ASMR можно рассматривать как совпадение метафоры киборга Харауэй и конструктивистской концепции быта, движения и техники.

\section{Ключевые слова}

youtube; медиафилософия; советская философия техники; конструктивизм; АСМР; Дзига Вертов

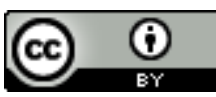

Это произведение доступно по лицензии Creative Commons «Attribution» («Атрибуция») 4.0 Всемирная. 


\section{«WE BELIEVE THAT THE TIME IS AT HAND WHEN WE SHALL BE ABLE TO HURL INTO SPACE THE HURRICANES OF MOVEMENT, REINED IN BY OUR TACTICAL LASSOES» (Vertov, 1922)}

The article «Constructivism» by Alexei Gan begins with a critique of traditional art. "When a pharmacist makes a box of pills, the product of his work has a definite ... purpose, when usage of it will be made, the product will be depleted». On the contrary, a work of art is supposed to have an endless effect on people. Gan writes that the traditional art pretends to reflect not only a very specific period of time and ideas of this time but also claims to never waste its relevance.

The new ideology must certainly start new processes in art, one of these processes is, as I believe, constructivism. Things, space, people and ideas must be endlessly organized with efficiency, here utilitarianism merges with aesthetics and form with content. According to Gan, there are three main concepts of constructivism: tectonics, facture, construction.

Tectonics «... is organically smelted and formed on the one hand from the properties of communism itself, and on the other hand from the use expediency of industrial material» (Gan, 1922, p. 61). That's why, in tectonics the issue of the synthesis of form and content can be resolved.

The concept of facture is associated with the processing of industrial material. A well-developed facture is a consciously taken material, which doesn't stop the movement of the design and doesn't limit its tectonics.

Design is the basic concept in constructivism, the definition of design is quite simple: design is the process of shaping an idea through the use of material.

The concept of tectonics supposes that the usage of the object should be clarified in its form. This means that the form must refer to the complex of material-discursive practices we can apply to the object. For example, when we go to IKEA, first we find ourselves in a labyrinth of rooms, each of these is situationally organised. There are no children in the room, for instance, but scattered pencils on a small pink asymmetric children's table next to a two-story bed covered with a blanket depicted a large dinosaur immerses us in the feeling of 
movement in this room. The movement is transferred into space, and although there are no children in the room, but the room makes a movement, showing a possible complex of children's bodies, soft toys, pencils, squeals and their inner work of connection, separation and ingression.

Gan argues that this can be applied not only to architecture, the task is to create a system of designing things in general.

"Undoubtedly, the affirmation of expedient constructiveness will turn out to be a more accurate affirmation of any art form, this latter will be nothing but a form of a new thing, which is real, as an action, will come into life" (Sidorina, 2012, p. 131).

In this context, constructive means not new, but necessary. The facture is associated with the «saving the energy of material», «beautiful and perfect as the most compressed in form». Constructivists are optimistic about standard production. Standard production allows to compress all movements of human. It is also important to say that crossing the personal-public boundary, especially the home-factory, allows the very organisation of life to aspire towards the organisation of automatic movement in general. According to Gan, such a simplification is necessary in order to «a technique gathered of external nature pieces and devouring a colossal living human power for organisational cohesion and cementing production acts [becomes] automatic elongated organs of society» (Gan, p. 64). We can give an example, a multi cooker - that is, the "cook" movement becomes an additional organ that connects, conjugates to the digestive system. Standard mass production cements production acts, makes cohesion stronger, creating a collective of things, the living and ideas.

Gan writes that technology is elongated organs of society, it is social technology. From this follows a rather radical position of Gan - the technique constructs human relations. It is also important that such a conception of technology is an alternative to understanding technology as serving a human. Gan introduces the phrase «social technology». Technique cannot be thought outside the collective. 
For Gan and Ginzburg, the basic concept is the labor collective, multitude, where power structures flicker but never totalise. This seems to be the main difference between their understanding of universality and totalitarianism. A collective is not only a collective of people, it's generally the living, things and ideas. In Gan's texts we can find another synonym for the collective - this is the «labor apparatus». To create a monumental movement that goes from the factory, where «an infinite number of steel monsters, rattling, hissing, belts interwoven with moving lines» are mated into the space of everyday life. It seems that the main difference between the previous forms of collectivity with non-machine tools is that the new collective has objects that produce movements in a form as compressed as possible.

«The design of a new life of a modern man will give a starting point for these searches, a concrete example of which will be industrial and engineering structures - the advanced outposts of a modern form» (Ginzburg, 1924, p.140).

Another constructivist Moisei Ginzburg suggests learning from the machines. «The machine, which we initially neglected and from which we then tried to isolate art, can now finally teach us how to build this new life» (Ginzburg, p. 88). According to Ginzburg, the meaning of the machine is the movement. This kind of movement, which a machine should teach us, should be organized in things. Things should offer us a machine movement that we can carry out together.

In such a consideration, the machine teaches us an interaction that took shape in neo-liberal logic: to measure our activity with the concept of efficiency and expediency. Thereby, the space for conjugation with non-human is increased.

The first thesis is that a thing should offer the movement. This means that we must abandon the perception of human as a conqueror of nature and the organizer of all things. People become mediators in the movement of things and participate in it not as the only Subjects. Modern capitalism, armed with the principles of constructivism, processes them into design principles, where the movement is smelted and sold in things: garlic presses, organizers for shoes, pens and garbage are riders 
of «vibrating matter» - the political ontology of things or the new collective organization of movement.

\section{«THE CYBORG IS A KIND OF DISASSEMBLED AND REASSEMBLED, POSTMODERN COLLECTIVE AND PERSONAL SELF» (Haraway, 1991b, p.3)}

This is a quote from Donna Haraway's Cyborg Manifesto. Haraway introduces the concept of «cyborg» to describe the current state of affairs. The technique is getting smaller: headphones, smart-phones, laptops, that we always carry with us and can put everywhere, our contact with it becomes more intimate. We can refer to the text of Paul Beatrice Preciado «Testo Junkie», where Preciado describes his experience of gender transition. Testosterone becomes the transferred movement of masculinity, Viagra becomes compressed movement of erection, and Phenazepamum is the movement of calmness. Any movement can be turned into a thing; from any identity can be melted the object, which stabilizes it. Preciado claims that gender is a prosthesis that organically exists in the materialism of the body.

Gender is a technology, the main movement of which is imitation, and the result is the formation of an organic prosthesis,

«which functions through the separation and fragmentation of the body: frames (shreds) organs and creates areas with high sensory and motor intensity (visual, tactile, olfactory ...), which after all defines both the natural and anatomical centers of gender differences» (Preciado, 2013).

Preciado's theory productively develops Butler's imitation concept (Butler, 1993), integrating physical materiality to her "gender is an imitation". In other words, the process of constructing gender is also associated with the construction of corporeal sensory experience, the technology of identity corporeal technology. The boundary between consciousness and matter ceases to exist in such a consideration. The movement of femininity can be expressed through a cultural image, for example, in the movements of the body of Carrie Bradshaw from 
'Sex in the city', or can be melted into the movement of things, for example, in a lamp for nails dryer.

Then we should place following questions: why do we need those body technology? and how can we correctly associate such constructivism with practices without falling into the trap of essentialism?

Pierre Bourdieu in two of his works - «The social space and genesis of groups» and «Social space and symbolic power» discusses the founding premise of the symbolic struggle, the struggle for recognition. Bourdieu begins with the fact that one of the characteristic features of present is uncertainty, or «the open meaning of the present». The existence of uncertainty, the absence of unified, fixed meanings of the present legitimizes the struggle with all its supplement strategies, which produce the meaning of the objects in the social world. If we try to think of the «closed meaning of the present», then we will find ourselves in the dystopia «1984», where «... history has stopped. There is nothing but an infinite present where the Party is always right».

And this uncertainty of the present encourages agents to define themselves, to develop categories of perception of the social world. And often this very supplement occurs either through an appeal to the past, which becomes preserved from the present, or to the future. Those practices determine and delimit the always open meaning of the present (Bourdieu, 2005, p. 22). In other words, the production of body technologies is necessary for withstanding the feeling of uncertainty, in order to endlessly answer the question of identity, to make our identity material, entering into a symbolic struggle for recognition. Buying a lamp for nails dryer is an attempt to close the «open meaning of the present».

Another social theorist, Cornelius Castoriadis, in his work «The Imaginary Establishment of Society» studies the nature of imaginary social meanings. The sense of imaginary meanings, whether it be a 'state', 'empire' or 'money', is practically elusive. Castoriadis writes:

«How can we comprehend God as an imaginary meaning? Only on the ground of the shadows cast by 'God' on the social movements of people» (Castoriadis, 2003, p. 151). 
In other words, we can say, the imaginary meaning is comprehended through the analysis of constructed movements.

\section{«A CYBORG IS A CYBERNETIC ORGANISM, A HYBRID OF MACHINE AND ORGANISM, A CREATURE OF SOCIAL REALITY AS WELL AS A CREATURE OF FICTION» (Haraway, 1991a, p.17)}

Haraway talks about the intimisation of technology, the same process also exist in media platforms. For example, videos from YouTube can be shared on Facebook, Twitter, and Telegram. YouTube video hosting itself can be compared with cinema, television and video art, because this is a platform where the distribution of the visual reaches a whole new level: the user can create content, distribute, comment, rate and, in general, settle in own Filter Bubble. In the book «Understanding Media», McLuhan writes that with the development of technical medium of communication, the new tool included the previous ones (1964). The camera obscura included a photography, the photography was part of the cinematography, in turn, the photography and cinematography were absorbed by the television and so on. Each time dealing with the Internet and the certain platform itself, we indirectly deal with all layers of media communication. The YouTube interface offers us a similar flow of visual information like $\mathrm{TV}$, but unlike the television flow, YouTube's flow is organized with the active participation of the user. In other words, the flow does not have linearity and a predetermined program. But also it seems productive to analyse in comparison YouTube as a platform and the history of media art. (Burgess, Green, 2009; Snickars \& Vondereau, 2009)

The first experiments of media art, since the release of the portable camera SONY PORTA PAK, consisted not so much in observing the world through the camera's eye, but concentrated on observing the artist for himself. At first glance, primitive and 'describing-nothing' videos as first works of Vito Acconci and Bruce Nauman incredibly captivated the artists. On the one hand, this is connected to the technical capabilities of the new camera. On the other hand, it was the influence of the Fluxus movement, which promoted art as a flow: the artist body was assigned as an instrument of art, the life of the artist or any process of creation served as a piece of art. In such videos, we 
see routine repetitive movements, the cyclical nature of the image (the same frames are used in the film several times with a calculated frequency), we see the shooting (camera from the screen) as in Wolf Vostell «Television Décollage», the camera is fixed in single point or takes off without operator intervention like Vito Acconci's «Steps» (1970).

Such experiments are not only a reflection on technological innovation, but also an attempt to find the body through the camera or even an attempt to merge together with camera, as in Gary Hill's «Crux», in which Gary Hill tied five cameras to his body, so the actions of each limb and his head were recorded when he went on a solo journey through the semi-wild terrain.

Rebecca Horn carried out completely different experiments in her work 'Berlin Exercises in Nine Pieces'. A static camera, a voyeur camera, we don't even think that there is a camera there, a camera that monitors the metamorphoses of the artist's body. Horn seeks to modify the body, expand its artistic capabilities, and turn into a mechanism that creates art.

The pioneers of media art were strongly influenced by the Dadaist movement and the first experiments with the surrealist celluloid. It is important to mention the influence of the Avant-garde first wave and especially the film "The Mechanical Ballet" by Fernand Léger. The film 'The Mechanical Ballet' was shot in 1924, dedicated to the experience of the wound that Fernand Léger experienced during the First World War. Fernand Léger wrote:

«... I was blinded by the lock of a $75 \mathrm{~mm}$ gun, the brilliance of its white metal in the bright sun. This fact taught me more than all the museums in the world. I found myself face to face with a real object, built by human hands, which in its work depended on geometric laws, because the geometric order prevails in mechanics» (It is a war! The destinies of artists during the First World War, 2014).

Léger's experience expressed through the film finds a new horizon of reflection throughout the works of Horn and Hill, but this is not only about a destructive collision with the machine, but how the machine could be integrated into the body of the artist. 
Rudolf Freiling in his article «Ohne Probe - Aspekte prozessualer Medienkunst» writes that the body and its control become the line of confrontation between the artist and the viewer, the latter can only observe the artist's actions through the «copper» screen. The camera-observer takes the viewer as a partner in the process of observation. Repeating single-word movements is the exploration of the body as an artistic tool (Freiling, 1997).

Such immersing in a trance a video performance confronts a classically passive viewer with an ambivalent situation: what is the planned part of performance and what is not? What can the body endure, what can the audience endure? intervene (turn off) or watch? The viewer is not dissolved in the action happening on the screen in comparison with traditional cinema, the viewer is an accomplice, she/he is the part of that video, which becomes both physical and mechanical machine. Machine, and the video screen, in this case, are a connecting mechanism of the process which is based on exchanging information both way between the «sender» and the «receiver», where the receiver is a viewer.

German video artist Ulrike Rosenbach is the first person who began using television as an object and as an art tool. In the podium discussion «!Wie aktuell ist frühe Videokunst?» in a conversation with Ursula Wevers she concludes that the first experiences, works and interactions of the artists with video camera are akin to videos on YouTube. That routine, immersing in trans, procedural videos have no difference from the videos, where the process of monotonous cleaning, folding clothes, or applying makeup are depicted (Martin, S., Rosenbach, U., Schavemaker, M. \& Wevers, U., 2009).

A very close similarity of media art experiments and such practices on the YouTube platform as ASMR can be found, these kinds of videos, according to statistics, are shot mostly by women, they call themselves ASMR artists. Dictionary.com defines ASMR as «Autonomous sensory meridian response (ASMR) is a calming, pleasurable feeling often accompanied by a tingling sensation. This tingle is said to originate in a person's head and spread to the spine (and sometimes the limbs) in response to stimulation. The stimuli that trigger ASMR vary from person to person. Some of the most common ones include whispers, white noise, lip smacking, having a person's complete 
attention (as in having one's hair cut by a hairdresser), as well as brushing, chewing, tapping, scratching, and crinkling». Now about more than 13 million ASMR videos are published on YouTube. These videos are similar to the works of video artists of 60s, 70s and 80s. Works such as Gary Hill's early video, "Primarily Speaking» where mouth and tongue sounds were recorded. Using the same speed, the spoken words «red», «blue» and «green» are cut into syllabic combinations that make up the soundtrack. Separate words, barely understandable during a conversation, are easier to «read» on evenly moving lips. Or «Theme Song» (1973) video by Vito Acconci, where on the screen we see the artist's mouth which in a quiet whisper mode persuades the camera not to stop recording him.

The second place got videos of «Eating», or in other words, videos in which people shoot the food process, there is a gross amount of such channels, sometimes these videos contain conversations, sometimes not. Similar video was created by Katharina Sieverding in «Life/Death», in which Katharina slowly licks the dripping from a spoon honey, the video consists of separate photos, which depict subtle, slow motion. In the first part of the video, Katharina, who turned her back to the viewer, also slowly takes her red cloak off, we don't see the artist's face, we don't understand who is in front of us, a woman or a man, the video lasts 40 minutes and our torment, caused by feeling of suspense, appears from the fact that this monotonous video doesn't end, but suddenly new object of perception was discovered, this object is our own process of perception.

The videos in the category «lifestyle» in which the authors clean, wash or sort something, could be connected with the works of the Womanhouse participants, created by Judith Chicago and Miriam Shapiro in order to reflect on woman's labor. Routine household chores, repeating shots of an already clean, but still wiped table. These videos do not carry any significant information but demonstrate regularity, immerse the viewer in a trance state, the monotony of movements calms. Artists engaged in similar video surveillance of their own actions studied their corporeality, sexuality, gender boundaries, as for example in that work of Katharina Sieverding «Life/Death», artists propagated the body as an instrument of art, or they mechanized the movement of the body and through the process of shooting 
domestic labor artists make the feminist statements and carry out the critique of female gender socialization.

\section{«UCHITES' BRAT' BYT!» (Gan,1923)}

We started the article with an attempt to interpret the concepts of «movement» and «technology» in constructivist writings, the aim of the constructivists was to bring «machine» into the everyday life, this should have been achieved by building the accurate and perfect movement, Dziga Vertov in «WE: VARIANT OF A MANIFESTO» continues the thoughts of constructivists, he pointed out that the object of 'kinochestvo', which would replace cinematography, is a perfect electric man who through the opening the "rhythm of things" reach the perfect, accurate movement.

"Cinema is, as well, the art of inventing movements of things in space in response to the demands of science; it embodies the inventor's dream-be he scholar, artist, engineer, or carpenter; it is the realization by kinochestvo of that which can not be realized in life. Drawings in motion. Blueprints in motion. Plans for the future. The theory of relativity on the screen. WE greet the ordered fantasy of movement» (Vertov, 1922).

Monotonous videos of household labor, ASMR, spreading on YouTube and gaining millions of views, can improve the constructivist thought. The movements will be transferred not only in everyday life, but in another space, which offers a wider set of tools for creating accurate movement, first of all, through a montage. But unlike a movie that is hermetically sealed, YouTube involves a greater number of participants in the interaction process, YouTube is a more accessible media platform, which easily could be integrated in our dailiness. Therefore, in contrast to the cinema, which works in the field of art, YouTube becomes a space for the construction and organization of movement, we can even say, the "monumental" movement that the constructivists wanted to reach. The fact is that the practice itself has completely shifted to the side of the machine, in other words, if we consider such an interaction, it becomes clear, we do not pull the machine into «our supreme Reality», but we interact in the body of the machine, interwoven into it in order 
to become transmitters of the movement created in the new collective. The example with monotonous videos is just an example of such an interaction, we can also give another example: through interacting with information in the media, firstly a person embodies it, for example, we gain ideal images of beauty, social status, wealth that we begin to imitate, not to copy, but then the most interesting thing arises, embodying media images a person returns it back to media, for example, in Instagram posts. The body turns into a medium, one of the channels of transmitting information from media to media, in this sense, exploding «inside-out». It seems, the following conclusion can be formulated: on YouTube a new type of movement is created, through which a person becomes a collective with machines-things-identities, but this new economy of movement is carried out not in the world of human bodies, but in the body of the machine.

Perhaps a comparison of the practices of media art and the practices created and broadcast via YouTube may seem odd, but the following phenomena will not seem accidental, in fact, bloggers and artists tend to reach a similar effect on the viewer. In an interview for her book «Cyborg Bodies», researcher Yvonne Volkart in the chapter «Extensive Bodies» talks with media artist and media theorist Jill Scott:

Yvonne Volkart: The body and technologies have always been located in the centre of your various enterprises as artist and media theorist and currently as the leader of a scientific research project about interfaces. From your point of view, what influence do new technologies have on the body and its perception?

Jill Scott: Yes, definitely, I think really there has been a significant influence, particularly through the fantasies available in media technologies. Media technologies such as virtual reality, or real time screen interaction, can blend the represented organic body with the imaginary digital image of the body (Volkart, 2007).

In «Cyborg Bodies» Yvonne also reflects on the fact that media technologies essentially support all those ideas where the body is understood as something composed, artificial and new. 
She supposes that new media technologies affect our body and our body perception in digital space. Reflecting on Haraway's ideas, Volkart suggests that we are always connected to our technological body through the screen. We can suppose that those fantasies that Jill Scott speaks about and those connections that Yvonne Volkart writes about are what subsequently realizes us as a cyborg. Creating your digital body on the Internet, communicating with the video actor and consuming images of his actions on YouTube, we create a digital connection, thereby prolonging our body in connection with electronics.

References

Bourdieu, P. (2005). Sociology of the social space. Moscow: Aleteya. (in Russian)

Butler, J. (1993). Bodies That Matter: On the Discursive Limits of «Sex». England: Routledge.

Burgess, J. E. \& Green, J. (2009). YouTube: online video and participatory culture. Cambridge: Polity.

Castoriadis, C. (2003). The Imaginary Institution of Society. Moscow: Logos.

Freiling, R. (1997). Ohne Probe - Aspekte prozessualer Medienkunst. Retrieved from http://www.medienkunstnetz.de/quellentext/44/

Gan, A. (1922). Constructivism. Tver: Tver's publisher. (in Russian)

Gan, A. (1923). Long Live the Demonstration of Everyday Life! Moscow. (in Russian)

Ginzburg, M. (1924). Style and Epoch. Moscow: State edition. (in Russian)

Haraway, D. (1991a). A Cyborg Manifesto. New York: Routledge.

Haraway, D. J. (1991b). Simians, cyborgs, and women: the reinvention of nature. London: Free Association Books.

Martin, S., Rosenbach, U., Schavemaker, M. \& Wevers, U. (2009). How current is early video art? Panel discussion. Retrieved from https://zkm.de/de/media/video/wie-aktuell-ist-fruehe-videokunst (in German)

McLuhan, M. (1964). Understanding Media: The Extensions of Man. New York: McGraw-Hill.

It is a war! The destinies of artists during the First World War. (2014).

Retrieved from 


\section{https://modernartconsulting.ru/2014/11/faith-of-artists-during-ww} i/ (in Russian)

Preciado, P. B. (2013). Testo Junkie. New York: The Feminist Press.

Sidorina, E. (2012). Constructivism without borders: studies and etudes on Russian Avant-garde. Moscow: Progress. (in Russian)

Snickars, P. \& Vondereau, P. (eds.) (2009). The YouTube Reader. Stockholm: National Library of Sweden

Vertov, Dz. (1922). «WE: variant of manifesto». Kino-Fot, (1), 25-31

Volkart, Y. (2007). Cyborg Bodies. Retrieved from http://www.medienkunstnetz.de/themes/cyborg bodies/

Список литературы

Burgess, J. E. \& Green, J. (2009). YouTube: online video and participatory culture. Cambridge: Polity.

Butler, J. (1993). Bodies That Matter: On the Discursive Limits of «Sex». England: Routledge.

Freiling, R. (1997). Ohne Probe - Aspekte prozessualer Medienkunst. Retrieved from http://www.medienkunstnetz.de/quellentext/44/

Haraway, D. (1991a). A Cyborg Manifesto. New York: Routledge.

Haraway, D. J. (1991b). Simians, cyborgs, and women: the reinvention of nature. London: Free Association Books.

Martin, S., Rosenbach, U., Schavemaker, M. \& Wevers, U. (2009). How current is early video art? Panel discussion. Retrieved from https://zkm.de/de/media/video/wie-aktuell-ist-fruehe-videokunst (in German)

McLuhan, M. (1964). Understanding Media: The Extensions of Man. New York: McGraw-Hill.

Preciado, P. B. (2013). Testo Junkie. New York: The Feminist Press.

Snickars, P. \& Vondereau, P. (eds.) (2009). The YouTube Reader. Stockholm: National Library of Sweden

Volkart, Y. (2007). Cyborg Bodies. Retrieved from http://www.medienkunstnetz.de/themes/cyborg bodies/

Бурдье, П. (2005). Социология социального пространства. Москва: Алетейя.

Вертов, Дз. (1922). «МЫ: вариант манифеста». Кино-Фот, (1), 25-31 
Ган, А. (1922). Конструктивизм. Тверь: Тверское издательство.

Ган, А. (1923). Ган. Да здравствует демонстрация повседневной жизни! Москва.

Гинзбург, М. (1924). Стиль и Эпоха. Москва: Государственное издание.

Касториадис, К. (2003). Воображаемое установление общества. Москва: Логос.

На войне как на войне. Судъбы художников в годы Первой мировой. (2014). Retrieved from https://modernartconsulting.ru/2014/11/faith-of-artists-during-ww i/

Сидорина, Е. (2012). Конструктивизл без берегов. Исследования и этюды о русском авангарде. Москва: Прогресс. 